\title{
Analisis Moralitas Individu Dalam Memoderasi Determinan Kecurangan Akuntansi
}

\author{
Indah Anisykurlillah \\ indah_anis@mail.unnes.ac.id \\ Sri Wardianti
}

Jurusan Akuntansi, Fakultas Ekonomi, Universitas Negeri Semarang

\begin{abstract}
.
This study aims to analyze the extent to which individual morality can moderate the factors that influence accounting fraud which consist of distributive justice, procedural justice, information asymmetry, organizational commitment, and competence.The population in this study were credit union managements in Semarang City with convieniece sampling technique and obtained 112 respondents. Data collection using a questionnaire and processed with the SmartPLS analysis tool 3.2.7. The results of this study indicate that distributive justice, procedural justice, information asymmetry, and competence have no significant effect on accounting fraud. While organizational commitment has a significant negative effect on accounting fraud. Individual morality is only able to moderate the influence of competence on accounting fraud. Based on the results of the study, it can be concluded that organizational commitment can reduce accounting fraud and individual morality can strengthen the influence of competence in increasing accounting fraud.
\end{abstract}

Keyword: Accounting Fraud; Individual Morality; Information Asymmetry; Justice; Organizational Commitment

\begin{abstract}
Abstrak.
Penelitian ini bertujuan untuk menganalisis sejauh mana moralitas individu dapat memoderasi faktor-faktor yang berpengaruh terhadap kecurangan akuntansi yang terdiri atas keadilan distributif, keadilan prosedural, asimetri informasi, komitmen organisasi, dan kompetensi. Populasi dalam penelitian ini adalah pengurus KSP di Kota Semarang dengan teknik pengambilan sampel convieniece sampling dan diperoleh sebanyak 112 responden. Pengumpulan data menggunakan kuesioner dan diolah dengan alat analisis SmartPLS 3.2.7. Hasil penelitian ini menunjukkan bahwa keadilan distributif, keadilan prosedural, asimetri informasi, dan kompetensi tidak berpengaruh signifikan terhadap kecurangan akuntansi. Sedangkan komitmen organisasi berpengaruh negatif signifikan terhadap kecurangan akuntansi. Moralitas individu hanya mampu memoderasi pengaruh kompetensi terhadap kecurangan akuntansi. Berdasarkan hasil penelitian, dapat disimpulkan bahwa komitmen organisasi dapat mengurangi kecurangan akuntansi dan moralitas individu dapat memperkuat pengaruh kompetensi dalam meningkatkan kecurangan akuntansi.
\end{abstract}

Kata Kunci: Asimetri Informasi; Keadilan; Kecurangan Akuntansi; Komitmen; Moralitas Individu 


\section{PENDAHULUAN}

Kecurangan akuntansi dapat diartikan sebagai perbuatan yang secara sengaja menguntungkan diri sendiri atau orang lain dengan suatu cara yang merugikan organisasi. Berdasarkan survei pendapat umum Global Corruption Barometer (GCB) tahun 2017 se-Asia Pasifik, sektor yang terkorup di Indonesia adalah sektor publik. Koperasi merupakan salah satu sektor publik yang dilirik sebagai solusi alternatif permodalan usaha mikro di Indonesia karena persyaratan kreditnya tidak terlalu ketat sehingga proses pencairan menjadi lebih cepat.

\begin{tabular}{lr}
\multicolumn{1}{c}{ Berdasarkan Peraturan } & Menteri \\
Koperasi dan & UMKM \\
No.11/Per/M.KUKM/2015 & tentang
\end{tabular}
Petunjuk Pelaksanaan Pemupukan Modal Penyertaan pada Koperasi, modal KSP dapat berasal dari pemerintah, salah satunya yaitu dana bergulir LPDB KUKM. Persyaratan untuk mengakses dana ini yaitu harus memiliki usaha yang bergerak dibidang koperasi atau UKM dengan jumlah anggota atau kelompok penerima manfaat minimal lima orang (lpdb.id 2016). Meskipun minat masyarakat untuk bergabung dan membentuk koperasi tinggi, namun terdapat fakta bahwa pembentukan beberapa koperasi hanya ditujukan untuk mendapatkan bantuan permodalan dari pemerintah. Dana LPDB tidak digunakan untuk operasional koperasi tetapi justru untuk memenuhi keperluan pribadi seperti kasus korupsi pada koperasi Artha Tunas Mulia Semarang dan KSP Agung Lestari Makassar. Kecurangan seperti ini menghambat perkembangan koperasi sehingga koperasi hanya mampu menjadi penyumbang kecil terhadap PDB Indonesia sebesar 4,48\% (Republika.co.id 2018).

Perlu adanya kajian mengenai halhal apa saja yang menyebabkan terjadinya kecurangan dalam koperasi agar dapat diminimalisir. Berdasarkan teori diamond fraud, elemen pertama fraud yaitu tekanan misalnya ketidakadilan organisasional secara distributif dan prosedural.

Penelitian Najahningrum (2013) dan Wu et al. (2016) menunjukkan bahwa keadilan distribusif dan prosedural berpengaruh negatif terhadap kecurangan. Pendistribusian penghargaan yang sebanding dengan kontribusi yang diberikan dan proses pengambilan keputusan yang adil akan dapat menekan kecurangan akuntansi. Sementara Wulandari \& Dhini (2016) menemukan bahwa keadilan distributif dan prosedural tidak berpengaruh terhadap kecurangan.

Elemen kedua kecurangan yaitu peluang. Penelitian Najahningrum (2013) dan Wulandari \& Dhini (2016) menemukan bahwa asimetri informasi yang semakin tinggi antara penyedia dan pemakai dapat meningkatkan peluang melakukan kecurangan. Sementara Indriani et al. (2016) menemukan bahwa asimetri informasi tidak berpengaruh terhadap kecurangan.

Elemen ketiga kecurangan yaitu rasionalisasi yang menjadi alasan pembenaran seseorang melakukan kecurangan. Penelitian Najahningrum (2013) menunjukkan bahwa dengan komitmen organisasi yang tinggi akan mendorong seseorang untuk memberikan usaha terbaik demi kemajuan organisasi dengan cara yang sehat dan berusaha menghindari kecurangan. Sementara Indriani et al. (2016) justru menunjukkan bahwa komitmen organisasi tidak berpengaruh terhadap kecurangan akuntansi.

Elemen keempat kecurangan yaitu kapabilitas, yang merupakan kemampuan dan kekuasaan untuk menentukan dan melakukan sesuatu di organsiasinya. Penelitian Pratomo et al. (2016) menunjukkan bahwa kompetensi berpengaruh positif terhadap kecurangan. 
Sementara Indriani et al. (2016) menunjukkan bahwa kompetensi tidak berpengaruh terhadap kecurangan.

Penelitian ini menggunakan moralitas individu sebagai variabel moderating. Penelitian Wulandari \& Dhini (2016); Indriani et al. (2016); dan $\mathrm{Wu}$ et al. (2016) menunjukkan bahwa moralitas individu secara konsisten berpengaruh negatif terhadap kecurangan. Level penalaran moral akan menentukan tindakan yang diambil seseorang dalam kondisi dilema etika. Level penalaran moral yang tinggi akan mendorong seseorang untuk lebih banyak melakukan tindakan yang benar (Liyanarachchi \& Newdick, 2009).

Tujuan penelitian ini adalah untuk menganalisis sejauh mana moralitas individu dapat memoderasi faktor-faktor yang berpengaruh terhadap kecurangan akuntansi pada Koperasi Simpan Pinjam (KSP) di Kota Semarang. Orisinalitas penelitian ini adalah menggunakan variabel moderating yaitu moralitas individu untuk memperkuat atau memperlemah faktor-faktor yang berpengaruh terhadap kecurangan akuntansi.

\section{KERANGKA TEORITIS DAN HIPOTESIS PENELITIAN}

Elemen pertama kecurangan dalam teori diamond fraud adalah tekanan. Salah satunya dapat disebabkan oleh ketidakadilan dalam pendistribusian penghargaan. Teori keadilan menjelaskan bahwa seseorang akan membandingkan outcome dan input yang mereka keluarkan dalam melakukan pekerjaan dan akan membandingkannya dengan yang diterima orang lain.

Hasil penelitian Najahningrum (2013) dan $\mathrm{Wu}$ et al. (2016) menunjukkan keadilan distribusif berpengaruh negatif terhadap kecurangan. Artinya, keadilan dalam pendistribusian penghargaan dipercaya dapat meminimalisir terjadinya kecurangan akuntansi. Penelitian Nawawi \& Ahmad (2017) menjelaskan bahwa ketidakpuasan atas penghargaan menimbulkan tingginya tingkat pergantian pegawai dan mendorong melakukan kecurangan sebagai ganti rugi atas rendahnya penghargaan yang diterima. Menurut Kartini (2018), penghargaan yang dapat mencukupi kebutuhan hidup membuat kinerja pegawai lebih fokus karena tidak perlu memikirkan penghargaan ekstra sehingga mengurangi pemikiran untuk mengambil peluang melakukan kecurangan. Berdasarkan uraian tersebut maka hipotesis pertama yang diajukan adalah:

\section{$\mathrm{H}_{1}$ : Keadilan distributif berpengaruh negatif terhadap kecurangan akuntansi.}

Ketidakadilan atas prosedurprosedur pengambilan keputusan menimbulkan emosi negatif seperti kinerja yang memburuk, timbulnya kebencian yang mengarah pada tindakan balas dendam melalui kecurangan. Menurut teori keadilan, seseorang menilai keadilan yang dirasakan terhadap proses untuk menentukan distribusi penghargaan. Najahningrum (2013) dan Wu et al. (2016) menunjukkan bahwa keadilan prosedural berpengaruh negatif terhadap kecurangan. Semakin adil maka pengurus akan semakin dapat menerima dan menunjukkan sikap positif terhadap keputusan yang diambil, sehingga akan mengurangi tindakan kecurangan. Berdasarkan uraian tersebut maka hipotesis kedua yang diajukan adalah:

$\mathrm{H}_{2}$ : Keadilan prosedural berpengaruh negatif terhadap kecurangan akuntansi.

Elemen kedua kecurangan dalam teori diamond fraud adalah peluang. Kesenjangan informasi antara agen dan 
prinsipal dapat menjadi peluang untuk melakukan kecurangan dengan tidak menyajikan secara lengkap informasiinformasi penting yang mempengaruhi keputusan pemakai atau menyajikan secara sesat. Hal ini dijelaskan dalam teori agensi melalui asumsi sifat dasar manusia dimana agen dan prinsipal saling berusaha untuk memaksimalkan kepentingan masing-masing. Pengurus sebagai pihak agen memiliki pengetahuan lengkap atas seluruh operasionalisasi koperasi dibandingkan anggota sebagai pihak prinsipal. Kondisi ini dapat dimanfaatkan untuk melakukan kecurangan. Hal ini didukung dengan penelitian Najahningrum (2013) dan Wulandari \& Dhini (2016) yang menunjukkan bahwa asimetri informasi berpengaruh positif terhadap kecurangan akuntansi. Berdasarkan uraian tersebut maka hipotesis ketiga yang diajukan adalah:

\section{$\mathrm{H}_{3}$ : Asimetri informasi berpengaruh positif terhadap kecurangan akuntansi.}

Teori diamond fraud menjelaskan bahwa rasionalisasi menjadi alasan pembenaran seseorang dalam melakukan kecurangan. Seseorang yang memiliki komitmen yang tinggi akan bersedia untuk memberikan usaha terbaik demi kemajuan organisasi secara sehat. Koperasi harus dapat memastikan bahwa pengurus memiliki komitmen yang tinggi serta menciptakan lingkungan kerja yang positif sehingga mendorong untuk melakukan yang terbaik dan menghindari perilaku curang. Hal ini didukung dengan penelitian Najahningrum (2013) yang menunjukkan bahwa komitmen organisasi bepengaruh negatif terhadap fraud. Berdasarkan uraian tersebut maka hipotesis keempat yang diajukan adalah:

\section{H4: Komitmen organisasi berpengaruh negatif terhadap kecurangan akuntansi.}

Elemen kecurangan keempat dalam teori diamond fraud yaitu kapabilitas. Fraudster yang memiliki kompetensi tinggi dapat memahami dan melaksanakan tugasnya dengan baik, bahkan dapat mengenali kelemahan pengendalian internal untuk melakukan kecurangan. Kekuasaan yang dimiliki dimanfaatkan untuk mempengaruhi orang lain agar terlibat dalam atau menyembunyikan kecurangan. Hal ini didukung dengan penelitian Pratomo et al. (2016) yang menunjukkan bahwa kompetensi berpengaruh positif terhadap fraud. Berdasarkan uraian tersebut maka hipotesis kelima yang diajukan adalah:

\section{H5: Kompetensi berpengaruh positif terhadap kecurangan akuntansi.}

Pengurus koperasi yang mempersepsikan bahwa penghargaan yang diterimanya telah sesuai dengan kontribusi yang diberikan akan merasakan keadilan. Sementara moralitas yang tinggi akan semakin meningkatkan motivasi untuk mengurus koperasi secara bertanggungjawab. Hal ini dijelaskan dalam teori perkembangan moral dimana dalam kondisi dilema etika, tindakan seseorang dipengaruhi oleh level penalaran moralnya. Level penalaran moral yang tinggi mendorong seseorang untuk memegang teguh prinsip etis demi keberhasilan koperasi secara sehat sehingga akan berusaha untuk menghindari perilaku curang yang merugikan. Penelitian Wulandari \& Dhini (2016); Indriani et al. (2016); dan Wu et al. (2016) menunjukkan bahwa moralitas individu secara konsisten berpengaruh negatif terhadap kecurangan akuntansi. Moralitas individu diduga mampu memperkuat pengaruh keadilan distributif dalam menurunkan kecurangan akuntansi. 
Berdasarkan uraian tersebut maka hipotesis keenam yang diajukan adalah:

\section{$\mathrm{H}_{6}$ : Moralitas individu memperkuat pengaruh keadilan distributif terhadap kecurangan akuntansi.}

Prosedur pengambilan keputusan dalam koperasi yang adil akan mengatasi suatu masalah ketidakadilan dengan melibatkan peran aktif seluruh pengurus koperasi. Apabila hal itu telah tercapai dan pengurus memiliki moralitas yang tinggi maka akan semakin meningkatkan motivasi untuk mengurus koperasi secara bertanggungjawab. Teori perkembangan moral menjelaskan bahwa tindakan yang dipilih seseorang dalam kondisi dilema etika dipengaruhi oleh level penalaran moralnya. Level penalaran moral yang tinggi akan mendorong seseorang untuk memperhatikan kepentingan yang lebih luas dan universal, sehingga akan berusaha untuk menghindari perilaku curang yang merugikan (Wilopo 2006). Penelitian Wulandari \& Dhini (2016); Indriani et al. (2016); dan $\mathrm{Wu}$ et al. (2016) menunjukkan bahwa moralitas individu secara konsisten berpengaruh negatif terhadap kecurangan akuntansi. Moralitas individu diduga mampu memperkuat pengaruh keadilan prosedural dalam menurunkan kecurangan akuntansi. Berdasarkan uraian tersebut maka hipotesis ketujuh yang diajukan adalah:

\section{H7: Moralitas individu memperkuat pengaruh keadilan prosedural terhadap kecurangan akuntansi.}

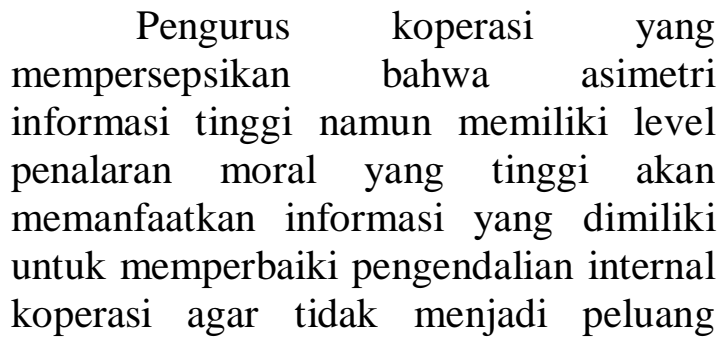

untuk melakukan kecurangan. Teori perkembangan moral menjelaskan bahwa tindakan yang dipilih seseorang dalam kondisi dilema etika dipengaruhi oleh level penalaran moralnya. Level penalaran moral yang tinggi akan mendorong seseorang untuk memegang teguh prinsip etis demi keberhasilan koperasi secara sehat dan berusaha untuk menghindari perilaku curang yang merugikan. Penelitian Wulandari \& Dhini (2016); Indriani et al. (2016); dan Wu et al. (2016) menunjukkan bahwa moralitas individu secara konsisten berpengaruh negatif terhadap kecurangan akuntansi. Moralitas individu diduga mampu memperlemah pengaruh asimetri informasi terhadap kecurangan akuntansi. Berdasarkan uraian tersebut maka hipotesis kedelapan yang diajukan adalah:

\section{H8: Moralitas individu memperlemah pengaruh asimetri informasi terhadap kecurangan akuntansi.}

Pengurus koperasi yang mempersepsikan memiliki komitmen dan moralitas yang tinggi akan memberikan usaha yang lebih untuk kemajuan koperasi dengan cara yang sehat. Teori perkembangan moral menjelaskan bahwa tindakan yang dipilih seseorang dalam kondisi dilema etika dipengaruhi oleh level penalaran moralnya. Level penalaran moral yang tinggi akan mendorong seseorang untuk memperhatikan kepentingan yang lebih luas dan universal (Wilopo 2006). Penelitian Wulandari \& Dhini (2016); Indriani et al. (2016); dan $\mathrm{Wu}$ et al. (2016) menunjukkan bahwa moralitas individu secara konsisten berpengaruh negatif terhadap kecurangan akuntansi. Moralitas individu diduga mampu memperkuat pengaruh komitmen organisasi dalam menurunkan kecurangan akuntansi. Berdasarkan uraian tersebut 
maka hipotesis kesembilan yang diajukan adalah:

\section{H9: Moralitas individu memperkuat pengaruh komitmen organisasi terhadap kecurangan akuntansi.}

Pengurus koperasi yang mempersepsikan memiliki kompetensi tinggi dapat membuka dan mengenali peluang untuk melakukan kecurangan. Namun dengan moralitas yang tinggi akan mengarahkan untuk menggunakan kemampuan dan kekuasaan yang dimiliki untuk mengelola dan mengembangkan koperasi secara sehat. Teori perkembangan moral menjelaskan tindakan seseorang dalam kondisi dilema etika dipengaruhi oleh level penalaran moralnya. Level penalaran moral yang tinggi akan memegang teguh prinsip etis demi keberhasilan koperasi secara sehat dan berusaha untuk menghindari perilaku curang yang merugikan. Penelitian Wulandari \& Dhini (2016); Wu et al. (2016); dan Indriani et al. (2016) menunjukkan bahwa moralitas individu secara konsisten berpengaruh negatif terhadap kecurangan akuntansi. Berdasarkan uraian tersebut maka hipotesis kesepuluh yang diajukan adalah:

\section{$\mathrm{H}_{10}$ : Moralitas individu memperlemah pengaruh kompetensi terhadap kecurangan akuntansi.}

\section{METODE PENELITIAN}

Penelitian ini merupakan penelitian kuantitatif dengan data primer. Populasi dalam penelitian ini adalah pengurus KSP di Kota Semarang sebanyak 52 unit yang terdaftar di Dinas Koperasi dan UKM Kota Semarang sejumlah 156 orang. Teknik pengambilan sampel menggunakan convinience sampling dan diperoleh jumlah kuesioner yang dapat diolah sebanyak 112 eksemplar. Teknik analisis menggunakan
SEM dan diolah menggunakan alat analisis SmartPLS 3.2.7.

Variabel kecurangan akuntansi diukur dengan indikator yang mengacu pada penelitian Wilopo (2006) meliputi kecurangan laporan keuangan, penghilangan bukti transaksi, kesalahan penerapan prinsip akuntansi secara sengaja, pencurian atau penyalahgunaan aset, dan perlakuan yang tidak semestinya terhadap aset.

Variabel keadilan distributif, diukur menggunakan indikator yang mengacu pada penelitian Najahningrum (2013) meliputi merefleksikan usaha yang diberikan, merefleksikan apa yang telah dikontribusikan untuk organisasi, dan sesuai dengan kinerja.

Variabel keadilan prosedural, diukur menggunakan indikator yang mengacu pada penelitian Najahningrum (2013) meliputi mengekspresikan pandangan dan perasaan, melibatkan pegawai atau diaplikasikan secara konsisten, tidak mengandung kepentingan tertentu, didasarkan pada informasi yang akurat, memungkinkan pemberian masukan dan koreksi, serta sesuai dengan etika dan moral.

Variabel asimetri informasi, diukur menggunakan indikator yang dikembangkan oleh Wilopo (2006) meliputi situasi dimana manajemen memiliki informasi yang lebih baik dari suatu aktivitas, lebih mengenal hubungan input-output, lebih mengetahui potensi kinerja, lebih mengenal teknis pekerjaan, lebih mengetahui pengaruh faktor eksternal, dan lebih mengerti apa yang dapat dicapai.

Variabel komitmen organisasi diukur dengan menggunakan indikator yang mengacu pada penelitian Najahningrum (2013) meliputi bekerja melampaui target, membanggakan organisasi kepada orang lain, menerima semua tugas, kesamaan nilai, bangga menjadi bagian organisasi, organisasi 
memberi inspirasi, gembira memilih bekerja pada organisasi tersebut, dan peduli terhadap nasib organisasi.

Variabel kompetensi diukur menggunakan indikator yang dikembangkan oleh Indriani et al. (2016) meliputi pemahaman terhadap cara kerja, prosedur kerja, proses kerja; pemahaman terhadap rencana dan target kerja; pemahaman proses kerja pada bagian lain; kemampuan penyesuaian diri, pengendalian diri, dan bekerja sama; kemampuan dalam menyampaikan gagasan dan pokok pikiran; serta penguasaan terhadap peralatan dan teknologi informasi.

Variabel moralitas individu diukur dengan indikator yang dikembangkan oleh Wilopo (2006) melalui kasus dilema etika yang diukur dengan 6 pertanyaan yang mencerminkan level penalaran moral seseorang.

\section{HASIL DAN PEMBAHASAN}

Menurut Ghozali (2014) uji model pengukuran (outer model) untuk mengetahui validitas konstruk melalui nilai Average Value Extracted (AVE) dan reliabilitas instrumen yang dinilai berdasarkan nilai cronbach's alpha dan composite reliability. Uji model struktural (inner model) untuk mengetahui hubungan kausalitas antar variabel yang dilihat melalui nilai $\mathrm{R}^{2}$ untuk mengetahui adanya pengaruh subtantif, $\mathrm{F}^{2}$ untuk melihat besarnya pengaruh masingmasing variabel independen terhadap variabel dependen, dan signifikansi dari koefisien parameter jalur struktural dengan rule of thumb dengan alpha 5\% pada pengujian one tail harus lebih dari nilai t-tabel (1,64). Tabel berikut menyajikan hasil uji outer dan inner model.

Tabel 1.

Hasil Pengujian Outer dan Inner Model

\begin{tabular}{|c|c|c|c|c|c|c|}
\hline Variabel & AVE & $\begin{array}{c}\text { Cronbach's } \\
\text { Alpha }\end{array}$ & $\begin{array}{l}\text { Composite } \\
\text { Reliability }\end{array}$ & $\mathrm{F}^{2}$ & $\mathrm{R}^{2}$ & $\begin{array}{c}\text { Statistik } \\
\text { Desktiptif }\end{array}$ \\
\hline $\begin{array}{l}\text { Kecurangan } \\
\text { Akuntansi (KA) }\end{array}$ & 0,669 & 0,910 & 0,875 & & 0,291 & $\begin{array}{l}\text { Sangat jarang } \\
\text { terjadi }(70 \%)\end{array}$ \\
\hline $\begin{array}{l}\text { Keadilan } \\
\text { Distributif (KD) }\end{array}$ & 0,919 & 0,978 & 0,972 & 0,000 & & Adil (44\%) \\
\hline $\mathrm{KD} * \mathrm{MI}$ & 1,000 & 1,000 & 1,000 & 0,017 & & \\
\hline $\begin{array}{l}\text { Keadilan } \\
\text { Prosedural (KP) }\end{array}$ & 0,691 & 0,939 & 0,945 & 0,000 & & Adil $(39,29 \%)$ \\
\hline $\mathrm{KP} * \mathrm{MI}$ & 1,000 & 1,000 & 1,000 & 0,015 & & \\
\hline $\begin{array}{l}\text { Asimetri Informasi } \\
\text { (AI) }\end{array}$ & 0,801 & 0,960 & 0,950 & 0,034 & & Rendah $(39,29 \%)$ \\
\hline $\mathrm{AI} * \mathrm{MI}$ & 1,000 & 1,000 & 1,000 & 0,007 & & \\
\hline $\begin{array}{l}\text { Komitmen } \\
\text { Organisasi (KO) }\end{array}$ & 0,591 & 0,920 & 0,902 & 0,095 & & $\begin{array}{l}\text { Berkomitmen } \\
(55,36 \%)\end{array}$ \\
\hline $\mathrm{KO}^{*} \mathrm{MI}$ & 1,000 & 1,000 & 1,000 & 0,024 & & \\
\hline Kompetensi (K) & 0,586 & 0,908 & 0,885 & 0,011 & & $\begin{array}{l}\text { Kompeten } \\
(62,5 \%)\end{array}$ \\
\hline $\mathrm{K}^{*} \mathrm{MI}$ & 1,000 & 1,000 & 1,000 & 0,046 & & \\
\hline $\begin{array}{l}\text { Moralitas Individu } \\
\text { (MI) }\end{array}$ & 1,000 & 1,000 & 1,000 & 0,111 & & $\begin{array}{l}\text { Postkonvensional } \\
(54,46 \%)\end{array}$ \\
\hline
\end{tabular}

Sumber: Output SmartPLS, 2018 
Nilai AVE telah lebih dari 0,50 dan nilai composite reliability maupun cronbach's alpha lebih dari 0,70 untuk masing-masing variabel sehingga dapat dikatakan valid dan reliabel. Nilai $\mathrm{R}^{2}$ 0,291 artinya variabilitas konstruk kecurangan akuntansi dapat dijelaskan sebesar $29,1 \%$ oleh variabel dalam penelitian ini, sisanya (70,9\%) dipengaruhi oleh variabel lain di luar model penelitian. Nilai $\mathrm{F}^{2}$ masing-masing variabel termasuk dalam kategori memiliki pengaruh yang lemah $(<0,15)$. Tabel berikut menyajikan ringkasan hasil pengujian hipotesis.

Tabel 2.

Ringkasan Hasil Uji Hipotesis

\begin{tabular}{|c|c|c|c|c|c|}
\hline \multicolumn{2}{|c|}{ Hipotesis } & \multirow{2}{*}{$\begin{array}{c}\text { Original } \\
\text { Sample } \\
-0,008\end{array}$} & \multirow{2}{*}{$\begin{array}{c}\mathrm{T} \\
\text { Statistik } \\
0,050\end{array}$} & \multirow{2}{*}{$\begin{array}{c}\mathrm{T} \\
\text { Tabel } \\
1,64\end{array}$} & \multirow{2}{*}{$\begin{array}{l}\text { Hasil } \\
\text { Ditolak }\end{array}$} \\
\hline $\mathrm{H}_{1}$ & $\begin{array}{l}\text { Keadilan distributif berpengaruh negatif } \\
\text { terhadap kecurangan akuntansi. }\end{array}$ & & & & \\
\hline $\mathrm{H}_{2}$ & $\begin{array}{l}\text { Keadilan prosedural berpengaruh negatif } \\
\text { terhadap kecurangan akuntansi. }\end{array}$ & 0,021 & 0,104 & 1,64 & Ditolak \\
\hline $\mathrm{H}_{3}$ & $\begin{array}{l}\text { Asimetri informasi berpengaruh positif } \\
\text { terhadap kecurangan akuntansi. }\end{array}$ & 0,184 & 1,642 & 1,64 & Ditolak \\
\hline $\mathrm{H}_{4}$ & $\begin{array}{l}\text { Komitmen organisasi berpengaruh negatif } \\
\text { terhadap kecurangan akuntansi. }\end{array}$ & $-0,360$ & 2,370 & 1,64 & Diterima \\
\hline $\mathrm{H}_{5}$ & $\begin{array}{l}\text { Kompetensi berpengaruh positif terhadap } \\
\text { kecurangan akuntansi. }\end{array}$ & 0,133 & 0,951 & 1,64 & Ditolak \\
\hline $\mathrm{H}_{6}$ & $\begin{array}{l}\text { Moralitas individu memperkuat pengaruh } \\
\text { keadilan distributif terhadap kecurangan } \\
\text { akuntansi. }\end{array}$ & $-0,199$ & 1,273 & 1,64 & Ditolak \\
\hline $\mathrm{H}_{7}$ & $\begin{array}{l}\text { Moralitas individu memperkuat pengaruh } \\
\text { keadilan prosedural terhadap kecurangan } \\
\text { akuntansi. }\end{array}$ & 0,200 & 1,118 & 1,64 & Ditolak \\
\hline $\mathrm{H}_{8}$ & $\begin{array}{l}\text { Moralitas individu memperlemah pengaruh } \\
\text { asimetri informasi terhadap kecurangan } \\
\text { akuntansi. }\end{array}$ & $-0,074$ & 0,769 & 1,64 & Ditolak \\
\hline $\mathrm{H}_{9}$ & $\begin{array}{l}\text { Moralitas individu memperkuat pengaruh } \\
\text { komitmen organisasi terhadap kecurangan } \\
\text { akuntansi. }\end{array}$ & $-0,195$ & 1,168 & 1,64 & Ditolak \\
\hline $\mathrm{H}_{10}$ & $\begin{array}{l}\text { Moralitas individu memperlemah pengaruh } \\
\text { kompetensi terhadap kecurangan } \\
\text { akuntansi. }\end{array}$ & 0,267 & 1,893 & 1,64 & Ditolak \\
\hline
\end{tabular}

Sumber: Output SmartPLS, 2018

\section{Pengaruh Keadilan Distributif terhadap Kecurangan Akuntansi}

Hipotesis pertama $\left(\mathrm{H}_{1}\right)$ ditolak, artinya keadilan distributif tidak berpengaruh sigifikan terhadap kecurangan akuntansi. Pengurus koperasi rata-rata mempersepsikan outcome yang mereka terima termasuk kategori adil, sehingga kecurangan akuntansi bukan disebabkan oleh adil atau tidaknya pendistribusian penghargaan, melainkan terdapat faktor lain yang menyebabkan demikian. Faktor yang mungkin menyebabkan kasus korupsi dana bergulir 
LPDB KUKM adalah mekanisme penyaluran yang kurang hati-hati (lpdb.id, 2018), sehingga peraturan penyaluran dana tersebut perlu ditegakkan. Menurut Najahningrum (2013), penegakan peraturan dapat mengurangi kecurangan akuntansi. Hal ini sejalan dengan langkah LPDB KUKM yang telah melakukan perbaikan SOP. Hasil penelitian ini sejalan dengan penelitian Wulandari \& Dhini (2016) dan yang menunjukkan bahwa keadilan distributif tidak berpengaruh terhadap kecurangan akuntansi.

\section{Pengaruh Keadilan Prosedural terhadap Kecurangan Akuntansi}

Hipotesis kedua $\left(\mathrm{H}_{2}\right)$ ditolak, artinya keadilan prosedural tidak berpengaruh sigifikan terhadap kecurangan akuntansi. Pengurus koperasi rata-rata mempersepsikan prosedur pengambilan keputusan termasuk dalam kategori adil, sehingga kecurangan akuntansi bukan disebabkan oleh adil atau tidaknya prosedur pengambilan keputusan melainkan terdapat faktor lain yang menyebabkan demikian. Faktor yang mungkin menyebabkan hal tersebut adalah kurangnya pengawasan dari badan pengawas internal koperasi. Salah satu kasus korupsi pada koperasi di Semarang dilakukan dengan cara memalsukan data pengurus dan nasabah serta memalsukan surat dari Dinas Koperasi dan UKM serta Perindag (Okezone, 2016). Hal ini seharusnya tidak terjadi jika badan pengawas koperasi berfungsi dengan baik. Berdasarkan UU No. 25 tahun 1992 tentang Perkoperasian, badan pengawas koperasi bertugas untuk melakukan pengawasan terhadap pelaksanaan kebijaksanaan dan pengelolaan koperasi, selain itu dengan wewenang yang dimiliki untuk meneliti catatan yang ada pada koperasi seharusnya pelanggaran tersebut dapat dideteksi dan dicegah.
Hasil penelitian ini sejalan dengan Wulandari dan Dhini (2016) yang menunjukkan bahwa keadilan prosedural tidak berpengaruh terhadap kecurangan akuntansi.

\section{Pengaruh Asimetri Informasi terhadap Kecurangan Akuntansi}

Hipotesis ketiga $\left(\mathrm{H}_{3}\right)$ ditolak, artinya asimetri informasi tidak berpengaruh sigifikan terhadap kecurangan akuntansi. Pengurus koperasi rata-rata mempersepsikan asimetri informasi termasuk dalam kategori rendah, namun bukan menjadi jaminan tidak terjadinya kecurangan. Hasil penelitian ini sejalan dengan Indriani et al. (2016) bahwa asimetri informasi tidak berpengaruh terhadap kecurangan akuntansi. Hal ini disebabkan karena banyak kasus korupsi saat ini yang melibatkan atasan dan bawahan secara bersama-sama dengan memanfaatkan informasi yang dimiliki, sehingga asimetri informasi tidak lagi berpengaruh terhadap kecurangan akuntansi.

\section{Pengaruh Komitmen Organisasi terhadap Kecurangan Akuntansi}

Hipotesis keempat $\left(\mathrm{H}_{4}\right)$ diterima, artinya komitmen organsiasi berpengaruh negatif signifikan terhadap kecurangan akuntansi. Pengurus koperasi rata-rata mempersepsikan memiliki komitmen yang tinggi dan kecurangan akuntansi termasuk dalam kategori sangat jarang terjadi. Hal ini berarti rendahnya kecurangan akuntansi salah satunya disebabkan oleh tingginya komitmen pengurus koperasi untuk mengurus koperasi secara bertanggungjawab. Mereka bersedia memberikan usaha terbaik demi kemajuan organisasi secara sehat, sehingga akan berusaha menghindari kecurangan. Atmosfer kerja yang positif dapat menjaga komitmen pengurus agar tidak melakukan 
kecurangan (Andrews et al, 2011). Hasil penelitian ini sejalan dengan Indriani et al. (2016) dan Najahningrum (2013) yang memperoleh hasil terdapat pengaruh negatif antara komitmen organisasi terhadap kecurangan akuntansi.

\section{Pengaruh Kompetensi terhadap Kecurangan Akuntansi}

Hipotesis kelima $\left(\mathrm{H}_{5}\right)$ ditolak, artinya kompetensi tidak berpengaruh signifikan terhadap kecurangan akuntansi. Pengurus koperasi rata-rata mempersepsikan dirinya kompeten. Hal ini berarti kecurangan akuntansi bukan disebabkan oleh tinggi atau rendahnya kompetensi pengurus koperasi. Kondisi ini dapat dijelaskan dengan fenomena korupsi di Indonesia yang telah merambah seluruh lapisan masyarakat, sehingga korupsi tidak lagi memandang latar belakang pelakunya. Hal ini sejalan dengan penelitian Indriani et al. (2016) yang menunjukkan bahwa kompetensi tidak berpengaruh terhadap kecurangan akuntansi.

\section{Pengaruh Moralitas Individu dalam Memperkuat Hubungan antara Keadilan Distributif terhadap Kecurangan Akuntansi}

Hipotesis keenam $\left(\mathrm{H}_{6}\right)$ ditolak, artinya moralitas individu tidak dapat memperkuat pengaruh keadilan distributif terhadap kecurangan akuntansi. Level penalaran moral yang tinggi tidak selalu menjadi jaminan bahwa ketika pendistribusian penghargaan telah adil akan menjadikan pengurus koperasi menghindari kecurangan. Peluang untuk melakukan kecurangan akan tetap ada jika penegakan peraturan tidak baik, seperti mekanisme penyaluran yang kurang hati-hati (lpdb.id, 2018). Pihak LPDB telah menerbitkan peraturan- peraturan baru mengenai penyaluran dana bergulir yang diharapkan dapat menjaga moralitas pengurus untuk tidak melakukan pelanggaran, dengan memberikan sanksi atas pelanggaran terhadap peraturan-peraturan tersebut.

\section{Pengaruh Moralitas Individu dalam Memperkuat Hubungan antara Keadilan Prosedural terhadap Kecurangan Akuntansi}

Hipotesis ketujuh $\left(\mathrm{H}_{7}\right)$ ditolak, artinya moralitas individu tidak dapat memperkuat pengaruh keadilan prosedural terhadap kecurangan akuntansi. Level penalaran moral yang tinggi tidak selalu menjadi jaminan bahwa ketika prosedur pengambilan keputusan telah adil akan menjadikan pengurus koperasi menghindari kecurangan. Peluang melakukan kecurangan akan tetap ada jika pengawasan dari badan pengawas internal koperasi tidak efektif, sehingga pengendalian internal menjadi lemah dan dapat dimanfaatkan untuk melakukan kecurangan. UU No. 25 tahun 1992 tentang Perkoperasian yang mengatur mengenai tugas dan wewenang badan pengawas koperasi diharapkan dapat meningkatkan peranan badan pengawas. Kehadiran badan pengawas seharusnya mampu menyadarkan pengurus bahwa segala keputusannya akan diawasi dan dievaluasi, sehingga diharapkan dapat menjaga moralitas pengurus untuk tidak melakukan kecurangan.

\section{Pengaruh Moralitas Individu dalam Memperlemah Hubungan antara Asimetri Informasi terhadap Kecurangan Akuntansi}

Hipotesis kedelapan $\left(\mathrm{H}_{8}\right)$ ditolak, artinya moralitas individu tidak dapat memperlemah pengaruh asimetri informasi terhadap kecurangan akuntansi. 
Seseorang pada level postkonvensional tidak selalu menjadi jaminan bahwa ketika terjadi ketidakseimbangan informasi, pengurus tidak akan mengambil kesempatan tersebut untuk melakukan kecurangan. Tekanan yang sangat berat, kompetensi yang dimiliki, dan dirasionalisasi, maka tidak akan menutup kemungkinan untuk memanfaatkan peluang tersebut untuk melakukan kecurangan. Hal ini seperti yang dijelaskan dalam teori diamond fraud.

\section{Pengaruh Moralitas Individu dalam Memperkuat Hubungan antara Komitmen Organisasi terhadap Kecurangan Akuntansi}

Hipotesis kesembilan $\left(\mathrm{H}_{9}\right)$ ditolak, artinya moralitas individu tidak dapat memperkuat pengaruh komitmen organisasi terhadap kecurangan akuntansi. Pengurus koperasi yang mempersepsikan memiliki komitmen serta level penalaran moral yang tinggi, tidak selalu menjadi jaminan bahwa pengurus koperasi tidak akan melakukan kecurangan. Hal ini sejalan dengan penelitian Indriani et al. (2016) dimana tekanan yang sangat berat dan kondisi pengendalian internal yang lemah dapat mengikis komitmen pengurus untuk tidak melakukan kecurangan.

\section{Pengaruh Moralitas Individu dalam Memperlemah Hubungan antara Kompetensi terhadap Kecurangan Akuntansi}

Hipotesis kesepuluh $\left(\mathrm{H}_{10}\right)$ ditolak dengan koefisien positif, artinya moralitas individu justru dapat memperkuat pengaruh kompetensi terhadap kecurangan akuntansi. Pengurus koperasi yang mempersepsikan memiliki keahlian dan kekuasaan untuk mengendalikan koperasi serta memiliki moralitas individu yang tinggi seharusnya dapat mengurangi kecurangan akuntansi. Namun keahlian dan kekuasaan tersebut justru digunakan untuk membuka dan memanfaatkan peluang untuk melakukan kecurangan. Meskipun pengurus memiliki moralitas tinggi namun jika mengetahui adanya peluang untuk melakukan kecurangan dapat saja tergiur untuk melakukan kecurangan. Oleh karena itu perlu diimbangi dengan pengawasan yang tinggi, maka akan mendorong pengurus melakukan kecurangan.

\section{SIMPULAN}

Berdasarkan hasil pengujian dapat disimpulkan bahwa keadilan distributif, keadilan prosedural, asimetri informasi, dan kompetensi tidak berpengaruh terhadap kecurangan akuntansi. Komitmen organisasi berpengaruh negatif terhadap kecurangan akuntansi. Moralitas individu hanya dapat memoderasi pengaruh kompetensi terhadap kecurangan akuntansi.

Saran bagi penelitian selanjutnya agar menggunakan variabel-variabel lain dalam pembahasan penelitian ini seperti penegakan peraturan, peranan badan pengawas, dan tekanan situasional, karena dalam penelitian ini pengaruh dari masing-masing variabel independen dalam kategori lemah dan kemampuan menjelaskan variabel dependen termasuk kecil. Selain itu juga menambahkan teknik wawancara selain kuesioner untuk mendokumentasikan informasi yang diperoleh dan dapat mendukung hasil penelitian.

\section{DAFTAR PUSTAKA}

Andrews, Martha C., Thomas Baker, dan Tammy G. H. (2011) 'Values and Person-Organization Fit: Does Moral Intensity Strengthen Outcomes?', Leadership \& Organization Development 
Journal, 32(1).

Ghozali, Imam. (2014) Structural Equation Modeling: Metode Alternatif Dengan Partial Least Square (PLS). Semarang: Undip.

Peraturan Menteri Koperasi Dan Usaha Kecil Dan Menengah Republik Indonesia Nomor

11/Per/M.KUKM/IX/2015

tentang Petunjuk Pelaksanaan Pemupukan Modal Penyertaan Pada Koperasi.

Indriani, Irma, Agus Suroso, dan Siti M. (2016) 'Penerapan Konsep Fraud Diamond Theory Dalam Mendeteksi Perilaku Fraud', Simposium Nasional Akuntansi XIX, Lampung.

Kartini, Kartini. (2018) 'Developing fraud prevention model in regional public hospital in West Sulawesi province', International Journal of Law and Management, 60(2).

Liyanarachchi, Gregory and Newdick C. (2009) 'The Impact of Moral Reasoning and Retaliation on Whistle-blowing: New Zealand Evidence', Journal of Business Ethics, 89(1).

Lpdb.id (2016) LPDB Sasar Pelaku Usaha Mikro Kecil Dan Menengah. Available at: http://lpdb.id/update/kabarlpdb/2016/08/15/lpdb-sasarpelaku-usaha-mikro-kecil-danmenengah/. Diunduh pada 2 Februari 2018.

Lpdb.id (2018) Koperasi Produktif Dapat Prioritas Dana Bergulir LPDB $K U K M . \quad$ Available at: http://lpdb.id/update/kabarlpdb/2018/04/26/koperasiproduktif-dapat-prioritas-danabergulir-lpdb-kumkm/. Diunduh pada 7 Agustus 2018.

Najahningrum, Anik F. (2013) 'FaktorFaktor Yang Mempengaruhi
Fraud: Persepsi Pegawai Dinas Provinsi DIY', Accounting Analysis Journal, 2(3).

Nawawi, Anuar and Ahmad Saiful A. P. S. (2017) 'Internal Control and Employees' Occupational Fraud on Expenditure Claims', Journal of Financial Crime.

Okezone.com (2016) Ketua Koperasi Di Semarang Didakwa Korupsi $R p$ 2,5 Miliar. Available at: https://news.okezone.com $/ \mathrm{read} / 2$ 016/04/18/512/1366219/ketuakoperasi-di-semarang-didakwakorupsi-rp2-5-miliar. Diunduh pada 31 Januari 2018.

Pratomo, Ananto, Bambang Agus P., dan Siti M. (2016) 'Analisis Fraud Diamond Terhadap Kecenderungan Perilaku Fraud Pada Pengelola Keuangan Pemerintah (Survey Pada Pengelola Keuangan Pemerintah Kabupaten X)', Simposium Nasional Akuntansi XIX, Lampung.

Rae, Kristy and Subramaniam, N. (2008) 'Quality of internal control procedures: Antecedents and moderating effect on organisational justice and employee fraud', Managerial Auditing Journal, 23(2).

Republika.co.id (2018) Koperasi Sumbang 4,48 Persen PDB Indonesia. Available at: http://www.republika.co.id/berita/ ekonomi/makro/18/01/05/p22jd4 383-koperasi-sumbang-448persen-ke-pdb-indonesia. Diunduh pada 31 Januari 2018.

Wilopo (2006) 'Analisis Faktor-Faktor Yang Berpengaruh Terhadap Kecenderungan Kecurangan Akuntansi: Studi Pada Perusahaan Publik Dan Badan Usaha Milik Negara Di Indonesia', Simposium Nasional 
Akuntansi IX Padang.

Wu, Mingzheng, Xiaoling S., Delin Z., Ci Wang. (2016). Moderated Mediation Model of Relationship Between Perceived Organizational Justice and Counterproductive Work Behavior' Journal of Chinese Human Resource Management
Article information. 7(2).

Wulandari, Retno dan Dhini S. (2016) 'Faktor-Faktor Yang Mempengaruhi Fraud Pada Satuan Kerja Pemerintah Daerah Kabupaten Temanggung', Accounting Analysis Journal, $5(2)$. 